Densitométrique de Radiographies D'Echantillons Prélevé à la Tarière sur des Abres Vivants. Aplication dans les domaines technologiques et physiologiques, thèse de doctorat, Université de Nancy, France, 206p. (1966). - Remmington, D. L., Whetten, R. W., Liu, B. H. and O’Malley, D. M.: Construction of an AFLP genetic map with nearly complete genome coverage in Pinus taeda. Theor. Appl. Genet. 98: 1279-1292 (1999)... - Ritter, E., Aragones, A., Markussen, T., Acheré, V. Espinel, S., Fladung, M., Wrobel, S., Faivre-Rampant, P., Jeandroz, S. and FAVRe, J. M.: Towards construction of an ultra high density linkage map for Pinus pinaster. Ann. For. Sci. 59: 637-643 (2002). Rozenberg, P. and Franc, A.: Modelling wood modules of elasticity using density profiles: methods and genetic effects. Second IUFRO Workshop: Connection between silviculture and wood quality through modelling approaches and simulation software. Kruger National Park, South Africa, August 26-31 (1996). - Rozenberg, P. and CAHAlan, C. Spruce and wood quality: genetic aspects. Silvae Genetica 46: 270-79 (1997). - Rozenberg, P., Franc, A. and Cahalan, C.: Incorporating Wood density in Breeding Programs for Softwoods in Europe: a Strategy and Asscociated methods. Silvae Genetica 50: 1-7 (2001). — SEDEROFF, R.: Building better trees with antisense. Nature Biotechnology $\mathbf{1 7}$ 750-751 (1999). - Sewell, M. M., Bassoni, D. L., Megrav, R. A. WheEler, N. C. and NeAle, D. B.: Identification of QTLs influencing wood property traits in loblolly pine (Pinus taeda L.). I. Physical wood properties. Theor. Appl. Genet. 101: 1273-1281 (2000). — SHAN, X. BLAKE, T. K. and TALBERT, L. E.: Conversion of AFLP markers to sequence-specific PCR markers in barley and wheat. Theor. Appl. Genet. 98: 1072-1078 (1999). - ShePard, M., Chaparro, J. X. and TEAS DALE, R.: Genetic mapping of monoterpene composition in an interspecific eucalypt hybrid. Theor. Appl. Genet. 99: 1207-1215 (1999). -
Siebert, P. D., Chenchick, A., KellogG, D. E., Lukyanov, K. A. and LUKYANOV, S. A.: An improved PCR method for walking in uncloned genomic DNA. Nucleic Acids Res. 23: 1087-1088 (1995). — THAMARUs, K., Groom, K., Murell, J. and Moran, G.: A genetic map and QTL analysis of wood and pulp traits in Eucalyptus globolus. Hybrid Breeding and Genetics of Forest Trees, Proceedings of QFRI/CRC-SNF Symposium, 9-14 April 2000, Noosa, Queensland, Australia, pp. 510-513. (Compiled by Dungey, H. S., Dieters, M. J. and Nikles, D. G.) Department od Primary Industries, Brisbane (2000). - VARGAS-HERNANDEZ J. and ADAMS, W. T.: Genetic relationships between wood density components and cambial growth rhythm in young coastal Douglas-fir. Can. J. For. Res. 24: 1871-1876 (1994). - Villar, M., LefÈVRe, F., BradshaW, H. D. and TeIssier DU Cros, E.: Molecular genetics of rust resistance in poplars (Melampsora larici-populina Kleb/Populus sp.) by bulked segregant analysis in a 2 × 2 factorial mating design. Genetics 143: 531-536 (1996). - Vos, P., Hogers, R., Bleeker, M., Reijans, M., van der Lee, T., Hornes, M., FriJters, A., Pot, J., Peleman, J., Kuiper, M. and ZABEAU, M.: AFLP: a new concept for DNA fingerprinting. Nucleic Acids Res. 23: 4407-4414 (1995). — Williams, J. G. K., KUBELIK, A. R., LivaK, K. J., RAFALSKI, J. A. and TINGEY, S. V.: DNA polymorphisms amplified by abitrary primers are useful as genetic markers. Nucl. Acids Res. 18 6531-6535 (1991). - Wu, R. L., Remington, D. L., MacKay, J. J., McKEAND, S. E., O'MALley, D. M.: Average effect of a mutation in lignin biosynthesis in loblolly pine. Theor. Appl. Genet. 99: 705-710 (1999). ZHANG, X. H. and CHIANG, V. L.: Molecular cloning of 4-coumarate: coenzyme A ligase in loblolly pine and the roles of this enzyme in the biosynthesis of lignin in compression wood. Plant Physiol. 113: 65-74 (1997). - Zobel, B. J. and van BuIJTENEN, J. P.: Wood variation: its causes and control. Springer-Verlag, Berlin, 363 pp. (1989).

\title{
Clonal Propagation of Dalbergia sissoo Roxb. by Softwood Nodal Cuttings: Effects of Genotypes, Application of IBA and Position of Cuttings on Shoots
}

\author{
By A. Husen*
}

Plant Physiology, Botany Division, Forest Research Institute, P.O. New Forest, Dehra Dun-248006, India

(Email: adroot92@yahoo.co.in)

(Received $9^{\text {th }}$ January 2003)

\begin{abstract}
Summary
Softwood nodal shoot cuttings were collected from the hedge garden at New Forest campus of Forest Research Institute, Dehra Dun. The cuttings were rooted in mist chamber to investigate the effect of IBA application and position of cuttings on shoots on rooting ability in different clones of Dalbergia sissoo Roxb. As compared to the $0 \%$ (control) and $0.1 \% ; 0.2 \%$ IBA showed maximum adventitious root formation. Overall percent rooting, percent sprouting, mean number of shoots and their length, mean number of roots and their length increased with increasing concentration of IBA. Among different positions of cuttings within the shoots, the best rooting response was recorded in the middle part followed lower and upper part. The findings exhibited significant interclonal variation regarding adventitious rooting and maximum response was observed in C42 (Gonda, Uttar Pradesh) clone. Interactive effect of clone C42 and middle position significantly increased percent sprouting while; interactive effects of middle position and $0.2 \%$ IBA treatment significantly increased percent rooting. It is concluded that the selection of genotypes with good rooting ability with respect to shoot position in hedged plants and concentration of IBA can be made to produce high quality planting stock material to start clonal forestry programme of $D$. sissoo.
\end{abstract}

* Present address for communication: Department of Botany, Faculty of Applied Science, University of Gondar, PO Box 196, Gondar, Ethiopia.
Key words: Dalbergia sissoo, IBA, position on shoots, clone, nodal cuttings, rooting.

\section{Introduction}

Dalbergia sissoo Roxb. commonly known as shisham is an important multipurpose tree species of Northern India. Traditionally, plantations of this species are raised through seedling resulting in large variation in growth, form, irregular seed setting and disease prone trees. In order to reduce plant variability and at the same time ensure increased productivity, the development of vegetative/clonal propagation techniques is required. For the production of high quality timber and faster tree growth, it is essential to start by selecting superior clones/trees from which the stem shoot cuttings are to be taken. Vegetative propagation of shisham and other tree species through stem cuttings is markedly affected by several factors (NANDA, 1970; HARTMANN et al., 1997). Several studies have demonstrated variation in rooting ability within genotypes on the same locations due to natural genetic variation (HAINes et al., 1992; Husen and PAL, 2003a). Positions from which cuttings are taken also influence the overall quality, its ability to root and subsequent growth habit (HARTMANN et al., 1997; ZAKARIA and ONG, 1982; TCHOUNDJEU and LEAKEY, 1996; HUSEN and PAL, 2003b). Adventitious root formation in juvenile 

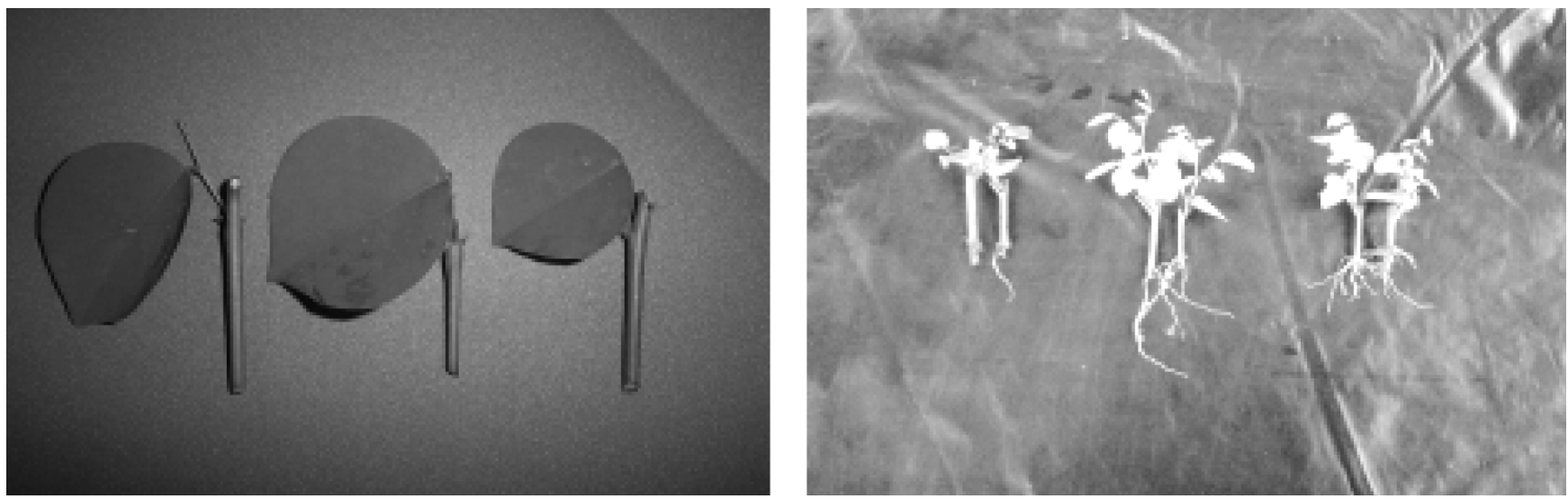

Figure 1. - Clonal Propagation of Dalbergia sissoo.

cuttings, which are obtained from shisham hedge gardens, is the most promising in terms of economics, ease and simplicity of the method for mass production of quality planting stock. Although successful vegetative propagation has been achieved in shisham (PAL, 1988), no information is currently available on the factors influencing rooting ability. Therefore, the present study was conducted to (1) compare rooting potential of cuttings collected from different clones, (2) the effect of position on rooting and (3) test the effects of applying a root-inducing powder i.e., indole-3-butyric acid (IBA) to enhance root initiation.

\section{Materials and Methods}

\section{Selection of clones}

Five different clones of Dalbergia sissoo namely C10 (Haridwar, Uttaranchal), C41 (Gonda, Uttar Pradesh), C42 (Gonda, Uttar Pradesh), C66 (Shergarh, Rajasthan), and C84 (Hanumangarh, Rajasthan) were selected for rooting trial.

\section{Collection and propagation of plant material}

Root suckers $50 \mathrm{~cm}$ long and 10-15 mm diameter were directly dug out from the selected candidate plus trees (CPTs) at various regions as mentioned earlier. They were wrapped in moist peat moss and brought to the laboratory in wet sacks. The root suckers from different CPTs were treated with 0.10 percent Bavistin (BASF India Ltd. Mumbai) for 10-15 minutes and placed horizontally in the nursery beds at New Forest Campus, Forest Research Institute (FRI), Dehra Dun in year 1998. Regular hedging was done yearly to maintain them as hedges and juvenile shoots were collected for multiplication. However, hedging in this experiment was done in the month of February, 2000 at $30 \mathrm{~cm}$ height and the upper portion of the coppiced stump was coated with chaupatia past, comprising mixture of $1 \mathrm{gm}$ copper carbonate and $1 \mathrm{gm}$ red led in 1 litre blue copper to avoid infection.

\section{Preparation of mono-nodal softwood cuttings}

The shoots were collected after eight week of hedging in April, 2000 and mono-nodal leafy, softwood cuttings were prepared. Total length of the cutting was approximately $4 \mathrm{~cm}$ (Figure 1). Twenty five cuttings were used per replicate and 3 replicates were maintained per treatment. Further, details of experimental design and statistical analysis are given under forthcoming paragraphs of statistical analysis.

\section{Treatments}

The cuttings were subjected to the following treatments: - a) position: shoots with 10-14 internodes were collected from five different clones. Each shoots were divided into three portions viz., upper, middle and lower; b) clones: as previously mentioned, the shoot cuttings were taken from hedge garden of five clones of D. sissoo namely C10, C41, C42, C66 and C84. The shoots emerged in hedge garden, FRI were made into cuttings and used for experimentation; c) dipping the basal ends into IBA. Treatments of IBA were included application of $0.2 \%$, $0.1 \%$ and $0 \%$ (untreated control) concentrations by basal dip method. The IBA was applied in its powder formulation, which also contain 0.05 percent Bavistin. The control cuttings similarly treated with talcum powder containing Bavistin only.

\section{Planting}

After treatments the cuttings were planted in plastic trays containing vermiculite $(\mathrm{pH} 7.0)$ which was presoaked for 24 hours in tap water before filling the trays to allow it to absorb the water. The trays were kept into a mist chamber under misting duration of 1 hour intervals and on delay of 60 seconds and off delay of 30 minutes. Inside the mist chamber, the relative humidity was maintained at $85 \pm 2 \%$ and maximum and minimum day/night temperature at $32 \pm 10^{\circ} \mathrm{C}$ to $26 \pm 10^{\circ} \mathrm{C}$ respectively.

\section{Observation on rooting response}

Rooting and sprouting on cuttings occur with 3-4 weeks after planting. However, after 30 days, the cuttings were carefully removed from the rooting medium and observation were recorded on percent rooting, percent sprouting, mean number of shoots and their length (in $\mathrm{cm}$ ) per cutting and mean number of roots and their length (in $\mathrm{cm}$ ) per cutting.

\section{Statistical analysis}

A factorial completely randomized design (CRD) was used for the statistical analysis of the data. Because the percentage

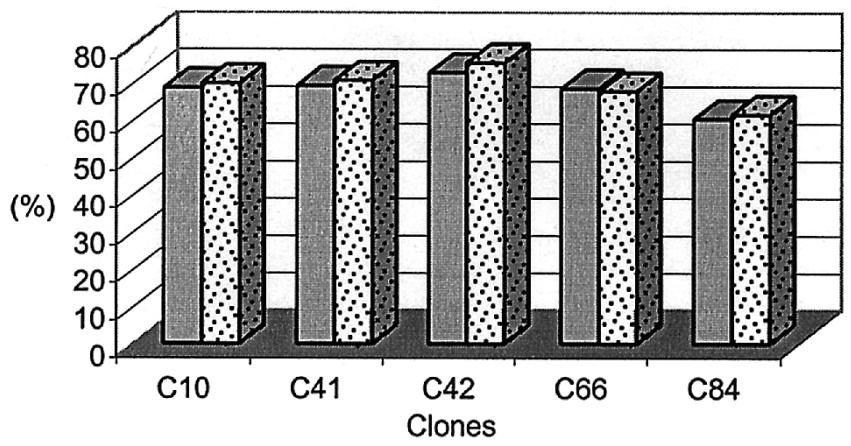

\section{口Percent rooting $\quad$ DPercent sprouting}

Figure 2. - Clonal variation in percent rooting and percent sprouting. 
Table 1. - Effect of IBA treatment, clone, position and their interaction on rooting and sprouting response of shoot cuttings taken from hedged plant of Dalbergia sissoo.

\begin{tabular}{|c|c|c|c|c|c|c|c|c|}
\hline \multirow[t]{2}{*}{ Parameters } & \multirow[t]{2}{*}{ Position } & \multirow{2}{*}{$\begin{array}{l}\text { Treatment of } \\
\text { IBA }\end{array}$} & \multicolumn{5}{|c|}{ Clone } & \multirow{2}{*}{$\begin{array}{l}\text { Mean of } \\
\text { position } x \\
\text { treatment }\end{array}$} \\
\hline & & & $\mathrm{C} 10$ & $\mathrm{C} 41$ & $\mathrm{C} 42$ & $\mathrm{C} 66$ & $\mathrm{C} 84$ & \\
\hline \multirow{16}{*}{$\begin{array}{c}\text { Mean } \\
\text { number of } \\
\text { shoots per } \\
\text { cutting }\end{array}$} & \multirow[t]{3}{*}{ Upper } & $0 \mathrm{ppm}$ & 1.77 & 1.86 & 2.33 & 2.97 & 2.95 & $2.38^{4}$ \\
\hline & & $1000 \mathrm{ppm}$ & 3.21 & 2.52 & 3.19 & 3.83 & 3.67 & $3.28^{\circ}$ \\
\hline & & $2000 \mathrm{ppm}$ & 3.57 & 3.04 & 4.11 & 4.70 & 4.67 & $4.01^{\star}$ \\
\hline & \multicolumn{2}{|c|}{ Mean of position $\mathrm{x}$ clone $\rightarrow$} & 2.84 & 2.47 & 3.21 & 3.83 & 3.76 & $3.22^{\#}$ \\
\hline & \multirow[t]{3}{*}{ Middle } & $0 \mathrm{ppm}$ & 2.29 & 1.99 & 3.18 & 3.17 & 3.00 & $2.72^{\circ}$ \\
\hline & & $1000 \mathrm{ppm}$ & 3.34 & 2.50 & 4.05 & 3.99 & 3.83 & $3.54^{\star}$ \\
\hline & & $2000 \mathrm{ppm}$ & 4.04 & 4.27 & 5.27 & 4.84 & 4.71 & $4.62^{\circ}$ \\
\hline & \multicolumn{2}{|c|}{ Mean of position $\mathrm{x}$ clone $\rightarrow$} & 3.22 & 2.92 & 4.17 & 4.00 & 3.85 & $3.63^{\#}$ \\
\hline & \multirow[t]{3}{*}{ Lower } & $0 \mathrm{ppm}$ & 2.59 & 1.95 & 3.47 & 3.09 & 2.98 & $2.81^{*}$ \\
\hline & & $1000 \mathrm{ppm}$ & 2.54 & 2.74 & 4.50 & 3.85 & 3.67 & $3.46^{\star}$ \\
\hline & & $2000 \mathrm{ppm}$ & 3.10 & 3.17 & 4.99 & 4.77 & 4.66 & $4.12^{+}$ \\
\hline & \multicolumn{2}{|c|}{ Mean of position $\mathrm{x}$ clone $\rightarrow$} & 2.74 & 2.62 & 4.32 & 3.88 & 3.77 & $3.47^{\#}$ \\
\hline & Treatment & $0 \mathrm{ppm}$ & 2.22 & 1.93 & 2.99 & 3.07 & 2.98 & $2.63^{\hat{v}}$ \\
\hline & of IBA x & $1000 \mathrm{ppm}$ & 3.03 & 2.58 & 3.91 & 3.89 & 3.72 & $3.43^{*}$ \\
\hline & clone $\rightarrow$ & $2000 \mathrm{ppm}$ & 3.57 & 3.49 & 4.79 & 4.75 & 4.68 & $4.26^{*}$ \\
\hline & Mean & clone $\rightarrow$ & 2.93 & 2.67 & 3.89 & 3.90 & 3.79 & \\
\hline Mean & Upper & $0 \mathrm{ppm}$ & 1.99 & 2.64 & 2.17 & 2.33 & 2.24 & $2.27^{\star}$ \\
\hline length of & & $1000 \mathrm{ppm}$ & 3.85 & 3.85 & 5.67 & 3.67 & 3.70 & $4.15^{\star}$ \\
\hline shoot per & & $2000 \mathrm{ppm}$ & 5.20 & 4.50 & 6.17 & 5.00 & 4.10 & $4.99^{\circ}$ \\
\hline cutting & Mean of po & ion $x$ clone $\rightarrow$ & 3.68 & 3.66 & 4.67 & 3.67 & 3.35 & $3.80^{\#}$ \\
\hline & Middle & $0 \mathrm{ppm}$ & 3.41 & 2.33 & 2.33 & 2.43 & 3.30 & $2.76^{\star}$ \\
\hline & & $1000 \mathrm{ppm}$ & 4.57 & 3.50 & 5.00 & 4.33 & 4.67 & $4.41^{\circ}$ \\
\hline & & $2000 \mathrm{ppm}$ & 6.05 & 5.17 & 5.50 & 5.00 & 5.07 & $5.36^{\circ}$ \\
\hline & Mean of po & ion $\mathrm{x}$ clone $\rightarrow$ & 4.67 & 3.67 & 4.28 & 3.92 & 4.34 & $4.18^{\#}$ \\
\hline & Lower & $0 \mathrm{ppm}$ & 2.28 & 2.33 & 2.60 & 2.50 & 2.33 & $2.40^{\circ}$ \\
\hline & & $1000 \mathrm{ppm}$ & 4.41 & 3.02 & 3.67 & 3.83 & 3.83 & $3.75^{\circ}$ \\
\hline & & $2000 \mathrm{ppm}$ & 5.82 & 3.89 & 5.17 & 4.67 & 4.33 & $4.78^{\circ}$ \\
\hline & Mean of po & ion $x$ clone $\rightarrow$ & 4.17 & 3.08 & 3.81 & 3.67 & 3.50 & $3.65^{\#}$ \\
\hline & Treatment & $0 \mathrm{ppm}$ & 2.56 & 2.43 & 2.37 & 2.42 & 2.62 & $2.48^{*}$ \\
\hline & of IBA $x$ & $1000 \mathrm{ppm}$ & 4.28 & 3.45 & 4.78 & 3.94 & 4.07 & $4.10^{*}$ \\
\hline & clone $\rightarrow$ & $2000 \mathrm{ppm}$ & 5.69 & 4.52 & 5.61 & 4.89 & 4.50 & $5.04^{*}$ \\
\hline & Mean & clone $\rightarrow$ & 4.17 & 3.47 & 4.25 & 3.75 & 3.73 & \\
\hline Mean & Upper & $0 \mathrm{ppm}$ & 2.73 & 2.16 & 3.33 & 3.33 & 3.40 & $2.99^{4}$ \\
\hline number of & & $1000 \mathrm{ppm}$ & 6.29 & 7.07 & 6.00 & 7.00 & 5.73 & $6.41^{\circ}$ \\
\hline roots per & & $2000 \mathrm{ppm}$ & 9.33 & 9.83 & 8.69 & 9.67 & 9.07 & $9.32^{\star}$ \\
\hline & Mean of po & ion $x$ clone $\rightarrow$ & 6.12 & 6.36 & 6.01 & 6.67 & 6.07 & $6.24^{\#}$ \\
\hline & Middle & $0 \mathrm{ppm}$ & 3.45 & 3.74 & 4.67 & 4.50 & 4.67 & $4.20^{\circ}$ \\
\hline & & $1000 \mathrm{ppm}$ & 7.18 & 8.42 & 8.67 & 8.20 & 7.67 & $8.02^{\circ}$ \\
\hline & & $2000 \mathrm{ppm}$ & 10.57 & 11.53 & 10.00 & 8.76 & 9.85 & $10.14^{\star}$ \\
\hline & Mean of po & ion $\mathrm{x}$ clone $\rightarrow$ & 5.07 & 7.89 & 7.78 & 7.15 & 7.39 & $7.46^{\#}$ \\
\hline & & $0 \mathrm{ppm}$ & 3.15 & 2.67 & 3.67 & 4.00 & 3.67 & $3.43^{\circ}$ \\
\hline & & $1000 \mathrm{ppm}$ & 7.07 & 6.51 & 8.02 & 7.33 & 8.67 & $7.52^{\star}$ \\
\hline & & $2000 \mathrm{ppm}$ & 9.60 & 8.76 & 9.51 & 9.07 & 9.74 & $9.34^{\star}$ \\
\hline & Mean of po & ion $x$ clone $\rightarrow$ & 6.60 & 5.98 & 7.07 & 6.80 & 7.35 & $6.76^{\#}$ \\
\hline & Treatment & $0 \mathrm{ppm}$ & 3.11 & 2.86 & 3.89 & 3.94 & 3.91 & $3.54^{*}$ \\
\hline & of IBA $x$ & $1000 \mathrm{ppm}$ & 6.85 & 7.33 & 7.56 & 7.51 & 7.35 & $7.32^{*}$ \\
\hline & clone $\rightarrow$ & $2000 \mathrm{ppm}$ & 9.83 & 10.04 & 4.90 & 9.16 & 9.55 & $9.59^{*}$ \\
\hline & Mean & clone $\rightarrow$ & 6.59 & 6.74 & 6.95 & 6.87 & 6.94 & \\
\hline & Upper & $0 \mathrm{ppm}$ & 2.54 & 3.03 & 3.03 & 3.07 & 2.67 & $2.87^{\star}$ \\
\hline length of & & $1000 \mathrm{ppm}$ & 4.33 & 4.50 & 4.74 & 4.69 & 4.33 & $4.52^{\circ}$ \\
\hline root per & & $2000 \mathrm{ppm}$ & 5.77 & 5.64 & 6.17 & 6.24 & 5.38 & $5.84^{\star}$ \\
\hline cuttıng & Mean of po & ion $x$ clone $\rightarrow$ & 4.21 & 4.39 & 4.65 & 4.67 & 4.12 & $4.41^{\#}$ \\
\hline & Middle & $0 \mathrm{ppm}$ & 3.06 & 3.11 & 3.68 & 2.87 & 3.00 & $3.14^{\star}$ \\
\hline & & $1000 \mathrm{ppm}$ & 4.69 & 5.00 & 4.88 & 4.35 & 4.83 & $4.75^{\circ}$ \\
\hline & & $2000 \mathrm{ppm}$ & 5.94 & 8.00 & 5.80 & 5.98 & 5.67 & $6.28^{\circ}$ \\
\hline & Mean of po & ion $x$ clone $\rightarrow$ & 5.57 & 5.37 & 4.79 & 4.40 & 4.50 & $4.72^{\#}$ \\
\hline & & $0 \mathrm{ppm}$ & 3.04 & 3.00 & 3.07 & 3.33 & 2.83 & $3.05^{\circ}$ \\
\hline & & $1000 \mathrm{ppm}$ & 5.39 & 5.16 & 4.69 & 5.00 & 4.29 & $4.93^{\circ}$ \\
\hline & & $2000 \mathrm{ppm}$ & 6.32 & 6.83 & 6.24 & 6.48 & 5.50 & $6.27^{\circ}$ \\
\hline & Mean of po & ion $x$ clone $\rightarrow$ & 4.92 & 5.00 & 4.67 & 4.94 & 4.24 & $4.75^{\#}$ \\
\hline & Treatment & $0 \mathrm{ppm}$ & 2.88 & 3.04 & 3.26 & 3.09 & 2.83 & $3.02^{*}$ \\
\hline & of IBA $x$ & $1000 \mathrm{ppm}$ & 4.88 & 4.8 & 4.77 & 4.68 & 5.52 & $4.73^{*}$ \\
\hline & clone $\rightarrow$ & $2000 \mathrm{ppm}$ & 6.01 & 6.82 & 6.07 & 6.23 & 5.51 & $6.13^{*}$ \\
\hline & Mean & clone $\rightarrow$ & 4.56 & 4.92 & 4.70 & 4.67 & 4.29 & \\
\hline
\end{tabular}

\# Mean of position, $\Delta$ Mean of IBA treatment, $\bullet$ Interactive mean of position and IBA treatment, and italic number represents three way interaction mean of position, clone and IBA treatment. 
Table 2. - Analysis of variance for the effect of clone, position, treatment of IBA and their interactions on rooting and sprouting parameters of Dalbergia sissoo.

\begin{tabular}{|c|c|c|c|c|c|c|c|}
\hline \multirow[b]{2}{*}{ Source of variation } & \multirow[b]{2}{*}{ df } & \multicolumn{6}{|c|}{ Mean sum of square } \\
\hline & & $\begin{array}{l}\text { Percent } \\
\text { rooting }\end{array}$ & $\begin{array}{c}\text { Percent } \\
\text { sprouting }\end{array}$ & $\begin{array}{c}\text { Mean } \\
\text { number of } \\
\text { shoots per } \\
\text { cutting }\end{array}$ & $\begin{array}{l}\text { Mean } \\
\text { length of } \\
\text { shoot per } \\
\text { cutting }\end{array}$ & $\begin{array}{l}\text { Mean } \\
\text { number of } \\
\text { roots per } \\
\text { cutting }\end{array}$ & $\begin{array}{l}\text { Mean } \\
\text { length of } \\
\text { root per } \\
\text { cutting }\end{array}$ \\
\hline Clone & 4 & $563.22^{*}$ & $697.32^{*}$ & $9.44 *$ & $2.92^{*}$ & 0.61 & 1.43 \\
\hline Position & 2 & $926.77^{*}$ & $659.83^{*}$ & 1.88 & $3.35^{*}$ & $16.67^{*}$ & 1.64 \\
\hline IBA treatment & 2 & $2128.82^{*}$ & $3068.44^{*}$ & $29.39^{*}$ & $75.57^{*}$ & $42.15^{*}$ & $109.07^{*}$ \\
\hline Clone $\mathrm{x}$ Position & 8 & 15.36 & $53.61 *$ & 0.62 & 1.09 & 1.85 & 0.67 \\
\hline Clone $x$ IBA treatment & 8 & 20.23 & 8.17 & 0.10 & 1.14 & 1.81 & 0.51 \\
\hline Position x IBA treatment & 4 & $82.31 *$ & 66.81 & 0.38 & 0.28 & 1.21 & 0.12 \\
\hline Clone $\mathrm{x}$ Position $\mathrm{x}$ IBA treatment & 16 & 42.18 & 39.54 & 0.19 & 0.43 & 0.80 & 0.37 \\
\hline Error & 90 & 20.64 & 19.40 & 0.82 & 0.57 & 2.49 & 0.69 \\
\hline \multicolumn{8}{|c|}{ Critical difference at $\mathrm{P}<0.05$ level } \\
\hline Clone & & 2.42 & 2.35 & 0.48 & 0.40 & - & - \\
\hline Position & & 1.87 & 1.82 & - & 0.31 & 0.65 & - \\
\hline IBA treatment & & 1.87 & 1.82 & 0.37 & 0.31 & 0.65 & 0.34 \\
\hline Clone $\mathrm{x}$ Position & & - & 4.07 & - & - & - & - \\
\hline Clone $\mathrm{x}$ IBA treatment & & - & - & - & - & - & - \\
\hline Position $x$ IBA treatment & & 3.25 & - & - & - & - & - \\
\hline Clone $\mathrm{x}$ Position $\mathrm{x}$ IBA treatment & & - & - & - & - & - & - \\
\hline
\end{tabular}

data are based upon a binomial response and some mean percentage lie outside the stable variance range of 30 to 70 percent, all percentage data were transformed to arcsine $\sqrt{ } \mathrm{p}$ following the method of ANDERSON and MCLEAN (1974). All other analyses were performed on untransformed data. Analysis of variance (ANOVA) procedures were used to test for significant treatment effects of the treatments on each variable measured (Table 2). In the ANOVA, the value for each replication was estimated based on all available cuttings and subjected to the following model:

$\mathrm{Y}_{\mathrm{ijk}}=\mu+\mathrm{p}_{\mathrm{i}}+\mathrm{c}_{\mathrm{j}}+\mathrm{t}_{\mathrm{k}}+(\mathrm{pc})_{\mathrm{ij}}+(\mathrm{pt})_{\mathrm{ik}}+(\mathrm{ct})_{\mathrm{jk}}+(\mathrm{pct})_{\mathrm{ijk}}+\mathrm{e}_{\mathrm{ijk}}$

Where, $\mathrm{i} \quad=1 \ldots 3, \mathrm{j}=1 \ldots 5$ and $\mathrm{k}=1 \ldots 3$

$\mu \quad=$ overall mean

$\mathrm{Y}_{\mathrm{ijk}} \quad=$ value of position $\mathrm{i}$, clone $\mathrm{j}$ and IBA treatment $\mathrm{k}$

$\mathrm{p}_{\mathrm{i}} \quad=$ effect of position $\mathrm{i}$

$c_{j} \quad=$ effect of clone $j$

$\mathrm{t}_{\mathrm{k}} \quad=$ effect of IBA treatment $\mathrm{k}$

$(\mathrm{pc})_{\mathrm{ij}}=$ interaction effect of position $\mathrm{i}$ and clone $\mathrm{j}$

$(\mathrm{pt})_{\mathrm{ik}}=$ interaction effect of position $\mathrm{i}$ and IBA treatment $\mathrm{k}$

$(\mathrm{ct})_{\mathrm{jk}}=$ interaction effect clone $\mathrm{j}$ and IBA treatment $\mathrm{k}$

$(\mathrm{pct})_{\mathrm{ijk}}=$ interaction effect position $\mathrm{i}$, clone $\mathrm{j}$ and IBA treatment $\mathrm{k}$

$\mathrm{e}_{\mathrm{ijk}} \quad=$ random error related to $\mathrm{Y}_{\mathrm{ijk}}$

\section{Results}

\section{Effect of clone}

Significant clonal variation was observed for the percent rooting, percent sprouting, mean number of shoots and their length per cutting at $\mathrm{P}<0.05$ level (Table 1 and 2). Maximum percent rooting $(72.63 \%)$ and percent sprouting $(75.23 \%)$ was observed on the cuttings from the $\mathrm{C} 42$ clone while minimum in clone C84 (Figure 2). More shoots were produced on the cuttings from the C66 clone than other clones (Table 1). Cuttings of $\mathrm{C} 42$ clone produced longer shoots $(4.25 \mathrm{~cm})$ followed by C10 $(4.17 \mathrm{~cm}), \mathrm{C} 66(3.75 \mathrm{~cm}), \mathrm{C} 84(3.73 \mathrm{~cm})$ and $\mathrm{C} 41(3.47 \mathrm{~cm})$ clones (Table 1).

\section{Effect of position}

The position of shoot, from which cuttings were taken, on the donor hedged plant had a significant effect on the percent rooting, percent spouting, mean length of shoot per cutting and mean number of roots per cutting (Table 1). The cuttings taken from the middle part of the shoots showed the highest percent rooting and percent sprouting followed by lower and upper part (Figure 3). However, mean length of shoot per cutting was higher in middle part followed by upper and lower part (Table 1). Further, the highest number of roots was recorded in middle part followed by lower and upper part (Table 1).

\section{Effect of IBA treatment}

All the rooting and sprouting parameters shows significant variation at $\mathrm{P}<0.05$ level (Table 2 ). Increasing the concentration of IBA increased percent rooting, percent sprouting, mean number of shoots and their length per cutting; and mean number of roots and their length per cutting (Figure 3 and Table 2). Therefore, the highest response was with its 2000 ppm concentration followed by $1000 \mathrm{ppm}$ and the lowest in control (0 ppm) cutting was recorded for all the studied parameters.

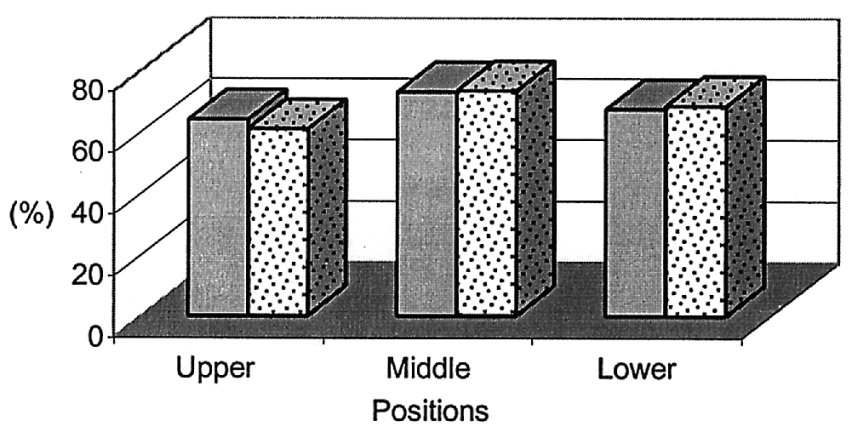

口Percent rooting

QPercent sprouting

Figure 3. - Effect of position of shoot on percent rooting and percent sprouting. 
(\%)

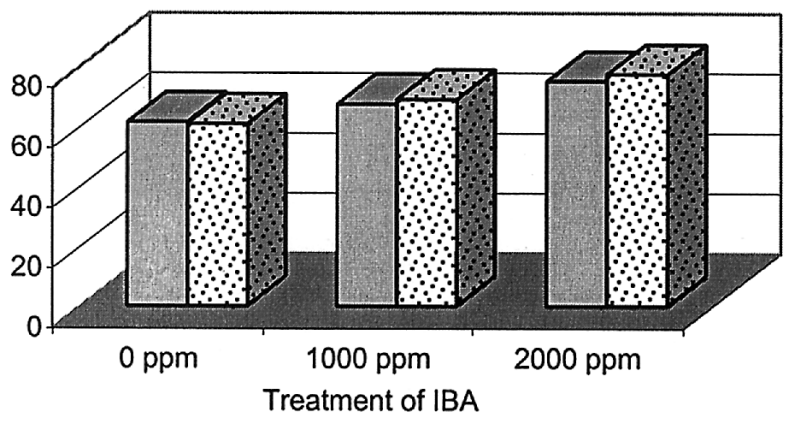

口Percent rooting $\quad$ OPercent sprouting

Figure 4. - Effect of IBA treatment on percent rooting and percent sprouting.

\section{Interactive effects}

The combined effects of clone and position was significant at $\mathrm{P}<0.05$ level for percent sprouting only (Table 2). Shoot cuttings taken from the middle part of the clone $\mathrm{C} 42$ exhibited the highest $(80.34 \%)$ percent sprouting. While, the lowest (58.89\%) was recorded in cuttings taken from the upper part of the clone C84 (Figure 5). Interactive effects of position and IBA treatment exhibited significant variation at $\mathrm{P}<0.05$ level for percent rooting only (Table 2 ). The percentage of adventitious root formation was the highest $(82.74 \%)$ in middle part of the cuttings that's were treated with $0.2 \%$ IBA than in any other combination. While, the lowest response $(56.99 \%)$ was recorded with control $(0 \%) \mathrm{x}$ upper part of the shoot cuttings (Figure 6). Further, it was observed that the two factors (clone $\mathrm{x}$ IBA treatment) and three factors (clone $\mathrm{x}$ position $\mathrm{x}$ IBA treatment) interaction effects on the studied rooting and sprouting parameters did not exhibited any significant variation at $\mathrm{P}<0.05$ level (Table 1 and 2).

(\%)

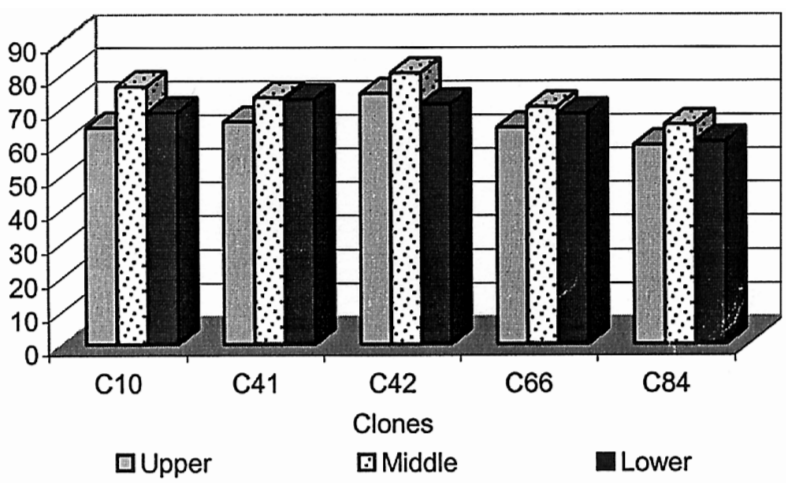

Figure 5. - Interactive effects of position and clone on percent sprouting.

(\%)

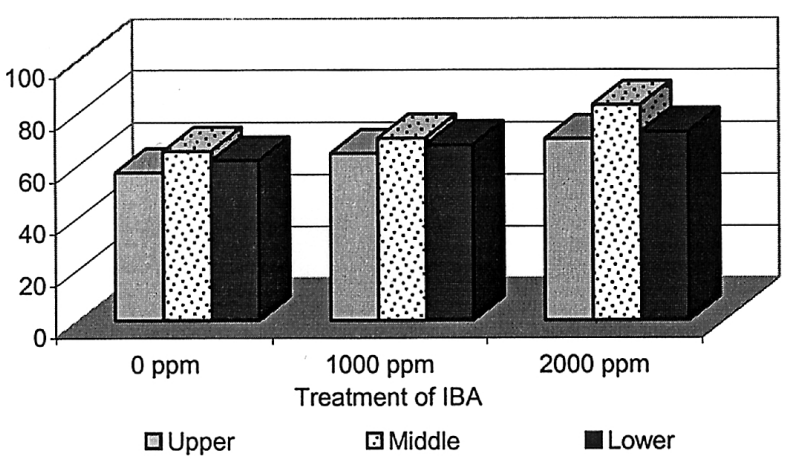

Figure 6. - Interactive effects of position and IBA treatment on percent sprouting.

\section{Discussion}

The findings clearly show that variation do exit with respect to rooting ability in the different genotypes of $D$. sissoo. Overall, clone C42 (Gonda, Uttar Pradesh) was the best genotype and maximum rooting and sprouting in cuttings taken from the middle part of the shoots were observed. Significant clonal variation in rooting behaviour was also reported earlier in various tree species (SNOW, 1939; HAINS et al., 1992; HUSEN and PAL, 2003a). Clonal differences in rooting ability of tree cuttings (HAissig and RiEmenschneider, 1988; Pounders and FosTER, 1992) and root and shoot growth (ZOBEL and TALBERT, 1984) are not uncommon in both angiosperms and gymnosperms (CunNinghaM, 1986). However, the reason for clonal variation are not fully understood, and may (NANDA and ANAND, 1970) or may not (GREENWOOD et al., 1976) be attributed to different concentration of endogenous auxins.

Differences existed in the position of shoot on hedged donor plants for rooting ability of the cuttings. Maximum rooting and sprouting percentage was observed in the cuttings taken from middle part followed by those taken from basal and minimum in the cuttings taken form the upper part. However, mean length of shoot per cutting was more in the cuttings taken from the same position but followed by upper and lower part. Similar results for percent rooting and percent sprouting were found in Tectona grandis (HUSEN and PAL, 2003b). Although, in most of tree species rooting ability of cuttings has been reported to increase from apical to basal part of the crown and of the shoots which has been attributed to accumulation of carbohydrates at the base of shoot (HARTMANN et al., 1997), there are many deviation from this general trend. For example, in Triplochiton scleroxylon, rooting percentage of cuttings form different node positions was found to decline basipetally (LEAKEY and MOHAMmed, 1985). Further, cuttings originating from the apical position of shoot of Milicia excelsa (OFORI et al., 1997) T. scleroxylon (LEAKEY, 1983) and Nauclea diderrichii (MATIN, 1989) displayed higher rooting percentages than those taken from the basal portions. But the results of this study indicate that cuttings of shoots originating from the middle part of shisham displayed higher rooting percentage. It is evident from these findings that optimal branch position for the best rooting response varies with the plant species, and the position effect on rooting may be caused by variation in the physiological status of shoot tissues with the position of branch on stock plant resulting in occurrence of gradients along the stem axis in the cellular activity, in the level of assimilates and growth regulators, and in the level of lignification etc.

Effect of IBA on rooting and sprouting ability of the cuttings also varied with position of the shoot and the concentration of IBA. Increasing the concentration of IBA increased rooting and sprouting of cuttings, which, were also taken form the middle part while it was comparatively less effective in cuttings taken from the other position. Similar findings were recorded in $T$. grandis (HUSEN and PAL, 2003b). Although, the effect of various auxins (IBA or NAA) in promoting rooting of cuttings is well known (NANDA, 1970; HARTMANN et al., 1997; Husen and Mishra, 2001; Husen and Pal, 2003b and c; Husen, 2003) but very little information is available on the effectiveness of auxins in relation to the branch position, especially when the cuttings were taken from the hedged garden.

Overall, the findings of this investigation suggest that selection of genotypes with good rooting ability with respect to shoot position in hedged plants and concentration of IBA can be made to produce high quality planting stock material to start clonal forestry programme of $D$. sissoo. 


\section{References}

Anderson, V. L. and McLean, R. A.: Design of Experiments; Marce Deckker Inc. New York (1974). - CunninghaM, M. W.: Evaluation of the Potential of Clonal Forestry for a Population of American Sycamore. North Carolina State University, Raleigh, NC. pp. 89 (1986). — GREENwood, M. S., Atkinson, D. R. and Yawney, H. W.: Studies of hard and easy-to-root ortets of sugar maples: differences are not due to endogenous auxin content. Plant Prop. 22: 3-5 (1976). - HAINES, P. I., WoNG, C. Y. and CHIA, E.: Prospects for the production of superior selection age phenotypes of Acacia mangium and A. auriculiformis. In: Breeding Technologies for Tropical Acacias. ACIAR Proceedings, No. 37 pp. 11-118 (1992). - Haissig, B. E. and Riemenschneider, D. E.: Genetic effects on adventitious rooting. In: Adventitious Root Formation by Cuttings, T. D. Davis, B. E. Haissig and N. Sankhla (eds.). Dioscorides Press, Portland, USA. pp. 47-60 (1988). - Hartmann, H. T., Kester, D. E., Davies, F. T. and Geneve, R. L.: Plant Propagation - Principle and Practices. $6^{\text {th }}$ Ed. Prentice-Hall of India Private Limited, New Delhi. pp 1-770 (1997). - Husen, A. and PAL, M.: Clonal propagation of Teak (Tectona grandis Linn. f.): effect of IBA application and adventitious root regeneration on vertically split cuttings. Silvae Gene. 52 (3-4): 173-176 (2003c). - Husen, A. and PAL, M.: Effect of serial bud grafting and etiolation on rejuvenation and rooting cuttings of mature trees of Tectona grandis Linn. f. Silvae Gene. 52 (2): 84-88 (2003a). — HuSEN, A. and MishrA, V. K.: Effect of IBA and NAA on vegetative propagation of Vitex negundo L. through leafy stem cuttings from hedged shoots during rainy season. Ind. Perf. 45 (20): 83-87 (2001). - HusEN, A. and PAL, M.: Clonal propagation of Tectona grandis Linn. f. by leafy stem cuttings: effects of branch position and auxin treatment on the rooting ability. Int. Conf. Qua. Tim. Pro. Teak Sus. For. Manag., 2-5 December 2003, Peechi, Kerala State, India (2003b). - HusEn, A.: Effects of IBA and NAA treatments on rooting of Rauvolfia serpentina Benth. ex Kurz shoot cuttings. Ann. For 11 (1): 88-93 (2003) - LFAKEY, R. R. B. and Mohammed, H. R. S.: Effects of stem length on root initiation in sequential single node cuttings of Triplochiton scleroxylon K. schum. Comm. For. Rev. 60: 117-126 (1985) - - LEAKEY, R. R. B. Stock Plant factors affecting root initiation in cuttings of Triplochiton Scleroxylon K. Schum an indigenous hardwood of West Africa. J. Hort. Sci. 58: 227-290 (1983). - Matin, M. A.: Carbon economy during rooting of cuttings of Nauclea diderrichii (De. Wild and Th. Dus.) Merill. M. Phil thesis, University of Edinburgh, United Kingdom (1989). - NANDA, K. K. and ANAND, V. K. Seasonal changes in auxin effects on rooting stem cuttings of Populus nigra and its relationship with mobilization of starch. Physiol. Plant. 23: 99-107 (1970). - NANDA, K. K.: Investigations of the use of Auxins in Vegetative Reproduction of Forest Plants. Final Report of PL 480 Research Project A 7FS-11 (FG In 255). pp. 1-215 (1970) - OFORI, D. Newton, A. C., Leakey, R. R. B. and Grace, J.: Vegetative propagation of Milicia excelsa by leafy stem cuttings: Effects of maturation, coppicing cutting length and position on rooting ability. J. Trop. For Sci. 10 (1): 115-129 (1997). - PAL, M.: Rooting stem cuttings of woody plant species. "Proc. Sym. Forest Biology in Service of Mankind", held at Madurai (1988). - Pounders, C. T. and Foster, G. S.: Multiple propagation effects on genetic estimates of rooting for western Hemlock. J. Am. Soc. Horti. Sci. 117: 651-655 (1992). — SNow, A. G. JR.: Clonal variation in rooting response of Red maple cuttings. USDA Forest Service, Northeastern For. Exp. St. Tech. Note No. 29. pp 2 (1939). - TchoundJEU, Z. and LEAKEY, R. R. B.: Vegetative propagation of African Mahogany: effects of auxin, node position, leaf area and cutting length New For. 11: 125-136 (1996). — ZAKARIA, I. and ONG, T. M.: Vegetative propagation of Yemane (Gmellina arborea) by stem cuttings Malay. For 45 (2): 282-284 (1982). - Zobel, B. J. and TAlBert, J.: Applied Forest Tree Improvement. John Wiley \& Sons. New York. pp. 1-105 (1984).

\title{
Sexual Asymmetry based on Flowering Assessment in a Clonal Seed Orchard of Pinus densiflora
}

\author{
By W. Y. CHOI ${ }^{1)^{*}}$, K. S. KANG ${ }^{1)}$, K. W. JANG ${ }^{2)}$, S. U. $\mathrm{HAN}^{1)}$ and C. S. KIM ${ }^{1)}$
}

(Received $8^{\text {th }}$ August 2003)

\begin{abstract}
Two equations were formulated in order to estimate the degree of sexual asymmetry for monoecious species. The concepts of the equations were formulated on the basis of the effective population numbers of female and male parents [i.e, $A_{s}^{(v)}$, and the differences of relative frequency between genders [i.e., $\left.A_{s}^{(x)}\right]$. These equations were applied to estimate the degree of sexual asymmetry based on the empirical data of flowering assessment in a clonal seed orchard of Pinus densiflora. The yearly variation in the production of female and male strobili was found. The effective population numbers at gamete levels $\left(v_{f}\right.$ and $\left.v_{m}\right)$ and clone level $\left(v_{b}\right)$ varied among 8 observation years. Both $A_{s}^{(x)}$ and $A_{s}^{(v)}$ were negatively correlated with effective numbers at gamete and clone levels. Averages of female and male strobilus production and estimates of sexual asymmetry were negatively correlated but the correlation was not
\end{abstract}

1) Tree Breeding Division, Forest Genetic Resources Department, Korea Forest Research Institute, 44-3 Omokchun, Kwonsun, Suwon, Kyonggi, 441-350, Republic of Korea.

2) Forest Tree Seed Center, Korea Forest Research Institute, 418-10 Joong-jang, Anmyun, Tean, Chungnam, 357-962, Republic of Korea.

*) To whom all correspondence should be addressed: Wan-Yong Choi, email: wychoi@foa.go.kr, tel: +82 312901111. significant. The correlations among effective number of clone $\left(v_{b}\right)$, arithmetic mean of female and male effective numbers $\left(v_{a}\right)$ and estimate of sexual asymmetry $\left[A_{s}^{(x)}\right]$ were strong and significant. Relatively larger difference between $v_{b}$ and $v_{a}$ were found when higher level of sexual asymmetry were observed.

Key words: sexual asymmetry, effective number, strobilus production, fertility, coefficient of variation.

\section{Introduction}

Pinus densiflora Sieb. et Zucc. is one of the important tree species from the aspects of utilization of forest resources and the management of forest ecosystem in Korea. The breeding program for this species has been performed since 1959 with a selection of plus trees and an establishment of 99 ha seed orchards (HAN et al., 2001a).

The main goals for establishing and managing seed orchards are the massive production of genetically improved seeds and the maintenance of genetic diversity present in seed orchards. Tree breeders want to maintain identical allelic structures between parental and offspring in seed orchard populations. However, this option can be expected only in the case of population under panmictic equilibrium. From this point of view, the maintenance of random mating among clones is one of the cru- 